\title{
A COMPARATIVE ANALYSIS OF PERCY BYSSHE SHELLEY AND FAIZ AHMED FAIZ
}

\author{
Aleena Hussain ${ }^{1}$, \\ Rubab Ali², \\ Amna Khali1 ${ }^{3 i}$ \\ Lahore Garrison University, \\ Pakistan
}

\begin{abstract}
:
Pakistani poets like Faiz or Habib Jalib have engraved their indistinguishable mark upon the sphere of renowned poets like Keats, Shelley and Wordsworth world. This study was undertaken to discern the similarities and differences between Faiz Ahmed Faiz and Percy Bysshe Shelley under the theoretical framework of the conflict theory proposed by Karl Marx. For this purpose, both poets' singular poems were selected: Mujh se pehli si muhabbat mere mehboob na maang and England in 1819. The textual analysis results of both poems conclude that although both poets are similar in their revolutionary and reformative ideas, their manner of expression differs. This study is limited in the sense that only singular poems were selected and dissected and this research is open for further research.
\end{abstract}

Keywords: Faiz Ahmed Faiz, Percy Bysshe Shelley, Conflict Theory, Karl Marx, England in 1819, Mujh se pehli si muhabbat mere mehboob na maang, revolutionary, reformative, analysis

\section{Introduction}

It can be stated without doubt that Pakistani writers and poets have carved their niche around the globe and are deserving of distinction, recognition and achievement in the literary circles of the world. One such name stands out of Faiz Ahmed Faiz, whose revolutionary ideas, patriotic zealotry and poetic aesthetic can be rivalled with the western counterparts such as Percy Bysshe Shelley. P. B. Shelley was a renowned English romantic poet for his ingenious and rebellious poetry. My goal in this paper is to highlight the distinct characteristics present in their style of poetry that set both the poets apart yet simultaneously similar, through the example of their published works.

For this purpose, this paper has been divided into five sections for an effective comparative analysis. The first section provides the literature review involving the notable works published on these two poets, followed by a subsection of the theoretical framework that is applied. The second and third sections of the paper highlight and detail first, Faiz Ahmed Faiz's

i Correspondence: email aleenah4507@gmail.com, rubaaab8@gmail.com, amnakhalil@lgu.edu.pk 
life and then of Percy Bysshe Shelley along with their poems, "Mujh se pehli si muhabbat mere mehboob na maang" and "England in 1819". Further, the fourth section illuminates the evident contrast between the two poets unraveled through the textual analysis of the mentioned poems. Afterwards, the fifth section concludes the overall research.

\section{Literature Review}

There has been comprehensive work done on the poetry of Faiz Ahmed Faiz. Benin (2020) thoroughly studied Faiz's poetic collections and concluded that Faiz is a universal poet, and it is imprecise to put any label on Faiz with any stamps of prejudice by dissecting the themes of love, patriotism, solitude, revolution, personal grieves, revolt, optimism, from within his poetry. A study conducted in 2016 probed Faiz's poetry's significance under the lens of neo-liberalism or corporate imperialism that champions unhampered flow of goods and services without the barriers of commerce or privatisation. Faiz's poetry contains Marxist ideology, a critique of capitalism and critical consciousness (Hayat and Rai, 97). Among relative other poetic works, the authors have also analysed the poem under discussion "Mujh se pehli si muhabbat mere mehboob na maang" and surmised that bourgeois historians dusted past economic disparities, bloodshed, anarchy, under the pseudo carpet of economic prosperity and social emancipation (102). Another study thoroughly analyzed the poetic body of work and exemplary testimonials through noteworthy translations concerning Faiz Ahmed Faiz to explore the perspective of resistance, violation and protest and presumed that Faiz inspired and urged people to fight and promoted revolutionary change (Magray, 15).

Without a doubt, the works of Percy B. Shelley have been widely analyzed. Through Shelley's published works, a study (2017) was conducted to reveal the vengeance and retribution abandonment and peaceful rebellion aspects by reconstructing him as a right-activist. It was deduced that Shelley was a restless cosmopolitan artist who desired a society teemed with justice and equality, expressed disdain for violent means, advocated revolution and rights of the lower classes of the society (Saleh and Khan, 359). He has been compared with the Pakistani revolutionary poet Habib Jalib to inspect the revolutionary causes of Nawaz and Awan (2019). Through data collection from various articles, newspapers, magazines, and research papers, the authors closely analyzed the political upheavals that result from feudalism, exploitation, corruption, inequality, injustice, and despotism. These social evils lead to agitation and unrest on a large scale that results in bringing about revolution (Nawaz and Awan, 295).

To identify the aspect of universality and humanitarian approach within Shelley and Faiz's poetry's ideological art, Saleh and Yusoff (2016) investigated the similarities and differences underlying the works of these poets within the context of their cultural and biographical differences. They concluded that both poets, although belonging to different eras, both poets revolted against tyranny and anarchy as well as supported internationalism of art as their ideological epiphany transcended the national barriers (Saleh and Yusoff, 71). However, this research is conducted to compare both Faiz and Shelley's singular poems under the microscope of the conflict theory proposed by Karl Marx. 


\subsection{Conceptual Framework}

The conflict theory is the conceptual framework applied for the comparative analysis of the two poets' ideas indicated through their selected poems. Karl Marx is known to formulate the conflict theory, according to which the change can be achieved through the conflicts and tensions that emerge through uneven and unequal dissemination of power, capital and resources in a society. The constant strive of the conflicting groups results in the achievement of development and progress instead of the commonly held notion that societies evolve and advance fluidly to elevated levels (Coser).

These conflicting groups of the society consist of the bourgeoisie and the proletariats, the powerful and the needy, and the justice holders and the criminal minds. These juxtapositioning sections of society constantly struggle to conduct and create situations for change of social, functional and economic nature. The conflicts arising from these groups' actions are the requisite conditions of change that is vital to rectify social injustices and inequalities (Mondal). Moreover, as Mondal (2015) related, the conflicting clashes, societal institutions, and offices continue to exist due to the influential circles' ability and motivation to establish and maintain the status quo. The dominant hold on major resources and positions within the society is held within the grasp of the bourgeoisie through their power, influence and wealth. The bourgeoisie is the community's minor group that retains control over a large scale production and capital. In contrast, the proletariat is the major working-class faction of the community that is oppressed and burdened with poverty. The conflicts that emerge from the strife between these two divisions give a surface to dissensions and discord in the spheres of politics, social structure, financial sector and other clusters of the social fabric (Crossman).

This theory's central presupposition is that competition is continual in all human interactions, including the social classes. Most significantly, when there is an imbalance of power, it can become a profound cause for the crisis. This competition is mainly for tangible resources like property and wealth but also for intangible goods as well; for example, domination, social status, or convenience (Koop). Mostly this competition is won or dominance is asserted by the "power elite". Charles Wright Mills is generally known as the pioneer of the modern social conflict theory, who gave the concept of the "tiny elite" and the description of the power struggle in society. This small group of "elite" comprises the bourgeoisie that has threads in the political, military, corporate and communal climate, who control the "others" (the common man) lives. The supposition that inequalities are maintained through the preservation of the social structure that bolsters such inequalities is generally committed by those individuals and groups that receive rewards and power benefits. The crucial assumption of this theory is that revolution and startling changes, on a massive scale, is an important effect and outcome of the power dynamic and struggle. Often this revolution and abrupt changes are brought by a resultant war that is considered as a unifier or cleanser of the society.

Given this conflict theory, the selected poems will be analyzed under the lens of other propositions as well, including culture, nationality, religion, politics and other social structures. The conflicts surrounding the class systems, discriminations and targeted customs of the social blanket that contribute to the ideas of revolution, uprising and change are closely examined. 


\section{Faiz Ahmed Faiz}

Faiz Ahmed Faiz was a teacher, an army officer, journalist, broadcaster and a poet. Faiz was born on February 13, 1911, in Sialkot to a wealthy landowning father who moved in the literary circles of Allama Iqbal (Pakistan's national poet). Faiz received his Bachelor's degree in Arabic, the Master's degree in English and subsequently in Arabic. He then pursued a teaching career first in the M.O.A College in Amritsar and later at the Hailey College of Lahore. The first poetic collection of Faiz called Naqsh-i-Faryadi (1943) was published while he was still studying at the Government College Lahore, including the poems "Aik Rahguzar Par" and "Teen Manzar" (InpaperMagazine). He was at the Afro-Asian writer's conference in Tashkent when General Ayub Khan led a military coup against the Pakistani government and seized control of the country. Upon Faiz's return, he was jailed for six months and later he moved to Karachi for a short time before returning to Lahore. In March 1951, he was arrested on the misconception of being a chief conspirator of the Rawalpindi conspiracy. The second collection of poetry of Faiz's was titled Dast-i-Saba (The Breeze's Hand) (1952), which was dedicated "to Kulsoom", his wife, followed by the third volume of poems called Zindan Nama (Prison Notebook) (1956) ("Faiz Ahmed Faiz"). These two collections were written during his four years imprisonment till 1955, which aided in his increased wide appreciation. He received the Lenin Peace Prize in 1962, which earned him greater recognition internationally. His fourth poetic collection Dast-e-Tah-e-Sang (1965) added to the already global prestige. During Zulfiqar Ali Bhutto's government, Faiz managed the Cultural Advisor position to the Ministry of Education and founded the Institute of Folk Heritage, the Lok Virsa, and the Pakistan National Council of the Arts (Inpaper Magazine). When Bhutto's ministry was overthrown to pave the way for martial law, Faiz was exiled to Beirut, Lebanon where he remained till 1982. He died in 1984 in Lahore. He was nominated for the Nobel Prize in the Literature category and awarded the Nishan-e-Haider, Pakistan's highest civil award, in 1990.

Faiz writes poetry that is quite distinctive, incorporating social issues and political elements in his poetry that set apart his poetry from his contemporaries' traditional romantic works. Faiz Ahmed wrote the poem "Mujh se Pehli si Muhabbat Mere Mehboob na Maang" at the time when he was part of the "All-India Progressive Writers' Association". This work is his first political poem. It addresses his beloved and overrules personal love for the passion of the miseries and turmoils faced by the Indian people before the partition of the subcontinent of 1947 (Hayat and Rai, 2). From adorning praises of his beloved and fantasies of reunion, Faiz transitions to relating the world's sad social circumstances. He integrates the pivotal issues of hunger, poverty, diseases, violence and the petty criminal workings that plague the society. The English translation of the original poem penned in the Urdu language is retrieved from the "O City of Lights: Faiz Ahmed Faiz Selected Poetry and Biographical Notes" written by Daud Kamal and Hassan Khalid for an effective critical comparison (Kamal and Hasan, 164).

The poem's opening stems from the narrator's realization of the unparalleled distinction between the worldly romantic love and the patriotic love one feels for his nation. The narrator gains awareness and consciousness of the world around him as if his eyes have opened up from a deep slumber of ignorance to observe and recognise his nation's deplorable state. The patriotic passion and love that the poet feels for his nation are beyond the seemingly inconsequential love 
for his beloved. The narrator requests his "mehboob" (beloved) to not demand and clamour for the love that existed between them as the narrator is unable to return the requisite emotions of worldly romantic love, that they shared before, towards his beloved in the words, "Mujh se pehli si muhabbat mere mehboob na maang" (Do not ask me for that past love).

In the next verses, the poet dives into the memory lane of the love shared between them and showers exceptional praises of his beloved. He remembers and affirms the time when the poet thought and believed wholeheartedly that the world perpetually shined and was illumined through the presence of the beloved. The beloved was responsible for the dazzling light, radiant glare, and brilliant spark of the poet's world as conveyed "Maine samjhaa tha ke tu hai to darakhshaan hai hayaat" (When I thought you alone illumined this world).

The poet presumed that the only sorrow in the world that was significant was the grief of the beloved beside whom the afflictions, problems and the predicaments of life ceased to matter, "Tera gham hai to gham-e-dehar ka jhagdaa kyaa hai" (And because of you/The griefs of this world did not matter). Faiz makes use of metaphysical conceit to describe the beauty of the beloved whose beauty, presence and countenance provided the eternal springs and stars their assurance, gleam and colours as he says, "Teri surat se hai aalam mein bahaaron ko sabaat" (Your beauty gave permanence to the colours of spring). The union with the beloved would have brought a sense of completion and achievement of destiny on the part of the poet "Tu jo mil jaaye to taqdir nigoon ho jaaye" (If I could only make you mine/Destiny would, forever, be in my hands). This characteristic of describing the extraordinary beauty of one's beloved can be exquisitely observed in other poets' works, for examples, of E. E. Cummings (The Love), Ahmed Faraz (Suna hai log use aankh bhar ke dekhte hain), John Donne (Air and Angels and The Sun Rising).

On the contrary, the poet has tasted a new kind of love after witnessing the unrest and disorder in his country. This patriotic love is more intense than his past romantic love for his beloved. Since he has felt the longing and the passion for his nation, this new experience has liberated him from the worldly tangible love as he is sensitive to more grave worldly griefs and afflictions that are more rapturous. He remembers and recounts the previous dark centuries that were decorated with brutalities wrecked by those in power and position. Now those ruthless atrocities are penned down with words wrapped in gold and silken embellishments, as historians try to veil the past cruelties and present them in a new soft light, "Anginat sadiyon ki taareeq bahemaanaa tilism/Resham-o-atlas-o-kamkhwaab mein bunvaaye hue" (On the dark loom of centuries/Woven into silk, damask, and goldcloth/Is the oppressive enigma of our lives). Moreover, this is a figurative illustration of the bourgeoisie's attempt to cloak the economic exploitation and financial atrocities that they impose on the proletariat to keep the poor masses unaware and under their control.

Furthermore, the engagements undertaken by the powerful to slant the resources and wealth in their direction results in a clash between the two prominent groups of the society i.e., the rich and poor. The poor fruitlessly try to overcome the economic disparities while the rich successfully maintain their power and influence, resulting in a crisis. This crisis is constant, just as the competition between these opposing groups gives air to society's conflicts. Due to the magnitude of immense deprivation, people are forced to partake in illegal and criminal activities of prostitution and human trafficking to soothe their hungry stomachs, eventually leading to death in the alleys of the marketplaces in drastic numbers, "Khaak mein lithade hue, khoon mein 
nehlaaye hue" (Throbbing between layers of dust - bathed in blood). The life of deficiency leads to the path where people had to turn to sinful livelihoods to survive and this is also evidently showcased by several of Saadat Hassan Manto's works like Hatak (The Insult), Sarkandon ke Peechhe (Behind the Reeds) and Kali Shalwar (The Black Shalwar).

He draws attention to the hunger, poverty and destitution that reek the nation, bringing in its wake diseases, pestilence and death, "Jism nikle hue amraaz ke tannooron se" (The furnace of poverty and disease disgorges body after body). The pain and misery that accompanies economic hardships can be rightly envisioned by the phrases of renowned poet Mir Taqi Mir who alludes to poverty as "death in daily episodes".

The poet addresses his beloved and asserts that your beauty and aura is unchanged, however, now he is unable to pray praises of his beloved's uncanny youth and beauty. He now cannot ignore the bloodshed, violence, wounds and lingering death around him. He cannot go back to live in ignorance after witnessing such horrendous cruelties. As the priorities of the narrator have been changed, he conceded that the love for his land and people is primary and takes precedence over the love of his beloved which has grown secondary although still alluring "Ab bhi dilkash hai tera husn, magar kya keeje?" (Your beauty is still a river of gems but now I know).

\section{Percy Bysshe Shelley}

Percy Bysshe Shelley was born on August 4, 1792, in England. He studied at first Syon House Academy and later at Eton. This was the time when he sought refuge in imaginative escapism from bullying and published two Gothic novels and two collections of sophomoric poetry. Shelley was admitted into the University College, Oxford, but was expelled in 1811, after which he eloped with and married Harriet Westbrook in his acts of rebelliousness. They travelled to Dublin, Lynmouth, Devon and North Wales where Shelley distributed political pamphlets endorsing freedom of Ireland, rights of roman Catholics and freethinking beliefs. He published his first prime poem, "Queen Mab" (1813). Shelley then eloped with Mary Wollstonecraft Godwin and travelled to France, Switzerland, Germany, and London. The death and will of his grandfather Sir Bysshe granted Shelley yearly proceeds which aided in overcoming his financial troubles. In the summer of 1816 spent in Geneva, Shelley drafted the poems "Hymn to Intellectual Beauty" and "Mont Blanc" (Reiman). In 1818, Shelley's epic Laon and Cythna was published as The Revolt of Islam after revision. He then travelled to Venice, Rome and Naples, where he stayed till February 1819. Shelley published his lyrical achievements, Prometheus Unbound (1820) and the drama The Cenci (1819), along with his finest poetic works, "Ode to Liberty", "Ode to the West Wind" and "To a Sky-Lark". Inspired by the Peterloo Massacre in England of August 1819, Shelley composed "The Masque of Anarchy" (Reiman). After moving to Pisa in 1820, he wrote the essay "A Defence of Poetry" which was published in 1840 . He died in July 1822 by drowning in Italy at the young age of twenty-nine years.

Percy B. Shelley was known as a British romantic poet and as an idealistic and social reformist. He wrote many poems on the current state of politics of his country and some of these works were deemed too radical for the time that they were published after his death. One such poem is the sonnet "England in 1819" which was crafted in December 1918 but was posthumously printed in 1839. 
This poem opens up with an outlook of distaste for the monarchy and ruling class, who survive on the toils of the common man. Shelley asserts the fact that King George III was blind and dying whereas his successor will also be incompetent to address the issues of the labour class, as stated: "An old, mad, blind, despxised, and dying King/Princes, the dregs of their dull race, who flow". This disdain and duplicity of the royal leaders are akin to the fictional decaying King Bérenger of "Exit the King" by Eugène Ionesco or the real-life alleged mad kings of the past like Henry VI of England (1421-1471) and Rudolf II, Holy Roman Emperor (1552-1612). The poet draws attention to the ineptitude and inability of the ruling powers by referring to the madness of the King and his clouded hereditary line hinted by the phrase "mud from a muddy spring", who instead of aiding the people, live off lavishly through their exploitation and confounding power. The question of genetics is raised by Shelley and hinted towards the acts of incestuous and inbreeding relationships among the royals to keep from marrying the commoners to preserve the royal bloodlines as pure (Evans).

He hints at the dreadful Peterloo massacre through the verse, "A people starved and stabbed in th' untilled field". On 16 August 1819, an armed cavalry directed by the local magistrates charged on the 60,000 protests in Manchester, England. Hundreds of the demonstrators were wounded while approximately twenty people were mercilessly killed in this scuffle. The crowd was protesting in a non-violent resistance manner against the Corn-laws that threatened economic slumps, famine and scarcity. This incident was tagged as the "Peterloo Massacre" by a radical newspaper in a sarcastic attempt as the site was the incident where the British had defeated Napoleon in 1815 in the Battle of Waterloo. Shelley has also referred to the Peterloo Massacre in his poem "The Masque of Anarchy" as Faiz Ahmed Faiz correspondingly writes about the carnage in Beirut "Aik Naghma Karbala-e-Beirut Kay Liay" (The Massacre of Beirut) while Saadat Hassan Manto has expressed his sorrow over the Jallianwala Bagh massacre in his short stories of Tamasha and 1919 ki Aik Baat (It Happened in 1919).

The country's poor folks will die for no reason due to the tyranny and persecution of its own nation's institutions of law, senate, religion and army. The poet attacks the judicial organization of the state created to appease the country folk, instead, the laws play the role of a two-edged sword quite like the ineffective judicial system mocked in "The Rape of the Lock" by Alexander Pope. The institution of religion has become Christless and hollow, similarly to the Church corruption depicted through The Canterbury Tales by Chaucer. The ruling class is compared to bloodsucking beeches to prey on the poor while sucking the blood, hard-earned livings and the peace of the people as they are compared to leeches, "But leechlike to their fainting country cling". This form of parasitic vampirism that absorbs the joy and livelihoods of others is similar to the abstract vampiric qualities of the Old Man from The Ghost Sonata by August Strindberg.

However, the sonnet ends with a note of optimism as Shelley hopes that people will rise against the tyranny and incite a revolution, change, and better things will come, just as the stormy revolution came after the ruthlessness of the French monarchy in A Tale of Two Cities by Charles Dickens. This illuminating change will bring back England's old traditions and institutions as he states, "Burst, to illumine our tempestuous day". The poet alludes to the "Glorious Revolution" of 1688-89, during which the oppressive rule of James II was shunned and ended. 


\section{Comparative Analysis}

Through the textual analysis of the poems, it is starkly evident that both poets wrote to inspire a revolution and liberty among the citizens of their nations. They expressed and painted vivid imagery of the sufferings and agony of the downtrodden folks who were suppressed under the weight and power of the ruling hegemonic social class. There is a certain sense of yearning present for a positive social and political change, revolution and transformation. Both the poets articulate the tumult of dispossession and destitution. In pointing out the flaws of the country's social fabric, there is a need for social reconstruction in their denouement of tyranny and oppression. The poems of both poets provide strength to the conflict theory derived by Karl Marx.

In "Mujh se pehli si muhabbat mere mehboob na maang" the poet sketched realistic imagery of the masses who are devoid of even the necessities of life and roam around the alleys and streets of the bazaars to earn a minimalistic wage to feed hungry stomachs. The uneven and unequal distribution of wealth, property, resources and capital forcefully drives the people stuck at the bottom of the economic ladder to try their hands at criminal undertakings such as prostitution. The lack of sufficient resources and money leaves the downtrodden masses without proper education and awareness, leading to a life of moral degradation and crimes. They are unwillingly plunged into the vicious circle of a hand-to-mouth lifestyle, which brings forth a torrent of unchecked and uncatered diseases and pestilence as they are unable to attain healthcare and other social facilities due to lack of financial support. In contrast, the bourgeoisie lives a life of lavishness, luxury and leisure, through their unflinching control of resources and riches. The ruling class exists in a bubble of flourishing funds and swarming supplies, therefore possessing the time and energy to indulge in whims and romantic overtures. Faiz Ahmed Faiz denounces such forms of personal love to draw attention towards more pressing needs and miseries of the proletariats. He writes, "Aur bhi dukh hai zamaane mein muhabbat ke siwaa" (There are afflictions which have nothing to do with desire). In this way, Faiz strays away from the traditional Urdu poetic conventions as stated by Dr Narang:

"Faiz demonstrates how a fine poet can transcend the circumscribing restrictions placed upon him by the conventions, for he has not only infused the conventions with socio-political meanings but at the same time retained their universal structures - erotic, mystic and spiritual" (Narang 69).

Percy B. Shelley also incorporates the principles of conflict theory in his poem "England in $1819^{\prime \prime}$ as he straightforwardly attacks the aristocratic class by addressing the King and pointing out moral deterioration among the royals by lighting a fire to scandalous rumours of inbreeding. He highlights the corruption and debauchery of societal and political institutions, i.e., army, religion, judicial system and parliament. These institutions are formed for the upheaval of justice and providence of security to the people; however, their actions provide the opposite acts of oppression and anarchy. This is a striking example of how the ruling class controls and manipulates to keep their power in authority and shifts the tide of resources to their favour due to their immense wealth and political connections. This manoeuvring of stockpiling assets leads to the constant competition between the two social groups along with afflictions, poverty and 
crime for the commoners, as emphasized in the poem of Faiz Ahmed Faiz. The Bourgeois or the tiny elite who are frantic in numbers suck out the peace and property of the people and leave them to indisposition through imposed harrowing taxes. When the starved masses protest against the injustices, their voices are crushed and their spirits stabbed, just as Shelley hinted at the dreadful Peterloo Massacre. Immersing the assumption of conflict theory regarding revolution and change on a mass scale, Shelley yearns for the proletariats to rise against the atrocities and incite a glorious revolution and transformation. The revolt and revolution thought by Faiz while writing this poem is brought about in the form of partition of the subcontinent in 1947.

Both Faiz Ahmed Faiz and Percy B. Shelley appear to be disillusioned by the governing organization of their country and inspire revolt and dissidence. Both detail the plight and poverty of the proletariat. Their works depict universalizability and everlasting elements as both poets are time, circumstances and nations apart. Both champion social change and are idealists and reformers as they appear to be committed towards social altruism.

However, they differ in respect to the part-subject matter regarding the selected poems, as Faiz talks about personal love and utters metaphorical praises in awe of the beauty of his beloved. In contrast, there is no mention of any romantic substance in Shelley's selected poem, who directly taunts and calls out the monarchs for their atrocities and inefficiency. While Faiz is more subtle and indirect in hinting towards the neglect of the administering body. He describes in detail the result and consequences of economic disparity by clueing at the dark side of poverty, i.e., human trafficking, prostitution and death. On the other hand, Shelley briefly talks about poverty and starvation while highlighting the corruption and unscrupulousness of societal institutions. He also alludes to the past incident of the Peterloo Massacre in an attempt to inform the consequences of the protest of the starving masses.

\section{Conclusion}

The evaluation of both the poems "Mujh se pehli si muhabbat mere mehboob na maang" and "England in 1819" through the lens of conflict theory by Karl Marx concludes that although the two ideologies of Faiz Ahmed Faiz and Percy Bysshe Shelley are similar in their reformative perspectives but differ in their portrayal of revolutionary ideas. Both the poets highlight social discrimination and economic disparity through their altruistic work, however, Shelley directly nominates the bourgeoise while Faiz is subtle and indirect in pointing fingers. On the one hand, Shelley sheds light on the corruption of the societal institutions, while Faiz casts aside personal love to illuminate the darker side of reality and poverty. The considerable limitation of this research paper is that only singular poems of Faiz and Shelley were textually examined for comparative analysis. This research is open for further study.

\section{Conflict of Interest Statement}

The authors declare no conflicts of interests. 


\section{About the Author}

Aleena Hussain is a student of Bachelor of Science in English Language and Literature at Lahore Garrison University, Pakistan, with a research interest in Feminist studies and South Asian Literature. The author has articles published in the aforementioned areas.

Contact: aleenah4507@gmail.com

Rubab Ali is a student of Bachelor of Science in English Language and Literature at Lahore Garrison University, Pakistan, with a research interest in Continental Literature, South Asian Literature and Psychoanalysis studies. The author has conducted multiple researches in the area of stylistic analysis and comparative analysis.

Contact: rubaaab8@gmail.com

Amna Khalil is a senior lecturer at Lahore Garrison University, Pakistan, with a research interest in South Asian Literature, Postcolonial Literature and Shakespearean studies. The author has multiple publication in the afore mentioned area of interest.

Contact: amnakhalil@lgu.edu.pk

\section{Work Cited}

Benin, Nikola. "Faiz Ahmad Faiz's poetry." 2020. Researchgate.com, https://www.researchgate.net/publication/339366687 Faiz Ahmad Faiz's poetry. Accessed 11 January 2021.

Coser, Lewis A. The Functions of Social Conflict. London: Routledge \& K. Paul, 1956. Print.

Crossman, Ashley. "Understanding Conflict Theory." Thoughtco.com Website, 3 July 2019, https://www.thoughtco.com/conflict-theory-3026622. Accessed 31 January 2021.

Evans, Charlie. "The Dangers Of Royal Inbreeding." Historyanswers.com Website, 18 April 2019, https://www.historyanswers.co.uk/kings-queens/queen-annes-real-favourite-therise-and-fall-of-sarah-churchill/. Accessed 2 February 2021.

"Faiz Ahmed Faiz." Poets.org, https://poets.org/poet/faiz-ahmed-faiz. Accessed 12 January 2021.

Hayat, Mazhar, and Shahida Parveen Rai. "Relevance of Marxist Poetry of Faiz Ahmed Faiz in the Age of Neo-liberalism." Journal of Research (Humanities), vol. LII, no. 1, 2016, pp. $97-$ 112. https://tehqeeqat.org/downloadpdf/938. Accessed 29 January 2021.

InpaperMagazine. "Faiz Ahmed Faiz: Life and poetry." Dawn, 17 February 2011, https://www.dawn.com/news/606752/faiz-ahmed-faiz-life-and-poetry. Accessed 12 January 2021.

Kamal, Daud, and Khalid Hasan. O City of Lights: Faiz Ahmed Faiz Selected Poetry and Biographical Notes. Karachi: Oxford University Press, 2006. Print.

Koop, Fermin. "What is conflict theory? Looking at Marx's main concepts." ZMEScience.com Website, 28 January 2021, https://www.zmescience.com/other/feature-post/what-isconflict-theory-19092019/. Accessed 31 January 2021.

Magray, Ahsan Ul Haq. "Faiz Ahmad Faiz: A Study of Resistance, Protest and Voice for Society in his Poetry." Creative Forum, vol. 33, no. 1-2, 2020, pp. 7-16. ResearchGate Website, 
https://www.researchgate.net/publication/346577907 Faiz Ahmad Faiz A Study of R esistance Protest and Voice for Society in his Poetry. Accessed 1 February 2021.

Mondal, Puja. “Top 5 Theories of Social Change - Explained.” Yourarticlelibrary.com Website, 18, November 2015, https://www.yourarticlelibrary.com/sociology/top-5-theories-ofsocial-change-explained/35124\#google vignette. Accessed 29 January 2021.

Narang, G. Ch. "Tradition and Innovation in Faiz Ahmed Faiz." Daybreak: Writings on Faiz. Yasmeen Hameed, ed. Karachi: Oxford University Press, 2013. Print.

Nawaz, Ali, and Abdul Ghafoor Awan. "A comparative study of P. B. Shelley and Habib Jalib as revolutionary poets." Global Journal of Management, Social Sciences and Humanities, vol. 5, no. 2, 2019, pp. 285-299. Researchgate.com Website, https://www.researchgate.net/publication/332858533 A COMPARATIVE STUDY OF PB SHELLEY AND HABIB JALIB AS REVOLUTIONARY POETS. Accessed 4 February 2021.

Reiman, Donald H. "Percy Bysshe Shelley." Encyclopedia Britannica, 31 July 2020, https://www.britannica.com/biography/Percy-Bysshe-Shelley. Accessed 22 January 2021.

Saleh, Husni Mansoor Nasser, and Farhana Khan. "P.B. Shelley: A humanist par excellence." International Journal of Applied Research, vol. 3, no. 11, 2017, pp. 357-360. Researchgate.com Website, https://www.researchgate.net/publication/322234006 PB SHELLEY A HUMANIST P AR EXCELLENCE. Accessed 4 February 2021.

Saleh, S., and Y. Jusoh Yusoff. "Universality of Percy Bysshe Shelley and Faiz Ahmed Faiz ideological art: A comparative study." Journal of Advanced Research in Social and Behavioural Sciences, vol. 4, no. 1, 2016, pp. 64-72. Akademia Baru, http://www.akademiabaru.com/doc/ARSBSV4 N1 P64 72.pdf. Accessed 11 January 2021. 
Creative Commons licensing terms

Author(s) will retain the copyright of their published articles agreeing that a Creative Commons Attribution 4.0 International License (CC BY 4.0) terms will be applied to their work. Under the terms of this license, no permission is required from the author(s) or publisher for members of the community to copy, distribute, transmit or adapt the article content, providing a proper, prominent and unambiguous attribution to the authors in a manner that makes clear that the materials are being reused under permission of a Creative Commons License. Views, opinions and conclusions expressed in this research article are views, opinions and conclusions of the author(s). and European Journal of Literature, Language and Linguistics Studies shall not be responsible or answerable for any loss, damage or liability caused in relation to/arising out of conflicts of interest, copyright violations and inappropriate or inaccurate use of any kind content related or integrated into the research work. All the published works are meeting the Open Access Publishing requirements and can be freely accessed, shared, modified, distributed and used in educational, commercial and non-commercial purposes under a Creative Commons Attribution 4.0 International License (CC BY 4.0). 